\title{
Introduction: student activism in an era of decolonization
}

\author{
Dan Hodgkinson and Luke Melchiorre
}

Scholarship on student activism in Africa has tended to be understood according to broader historical periodizations of elite African politics. This has largely been because of student activists' historical claims to be 'aspirant elites' (Cruise O'Brien 2003: 172). As such, scholars have explored student activists' role in anti-colonial nationalism in the mid-twentieth century, anti-structural adjustment and democratization protests since the late 1980s, and more recently in the resurgence of 'Fallist' student protests in South Africa (Nyamnjoh 2016; Booysen 2016; Heffernan et al. 2016). This special issue challenges these periodizations by exploring the histories of student activism during the era of decolonization immediately before and after independence. As the articles in this special issue demonstrate, unlike the first generation of nationalist leaders who had refined their emancipatory anticolonial politics on campuses abroad, African students in the era of decolonization did so through geographies that spanned both foreign institutions and newly created African universities. Inspired by Marxist-Leninism and Pan-African solidarity, these students often came to embrace transformational revolutionary politics during their university experiences. In many instances, their own expectations and political activities would come to challenge, upset and dramatically contest the designs of newly independent African states. The articles collected in this special issue, and first presented at a workshop entitled 'Student Activism Reconsidered' at the University of Oxford in July 2016, seek to develop understandings of African student activism during this critical period by revisiting postcolonial Africa's first student protests and experiences of university life. Many of the debates that these students initiated on campus would come, in subsequent decades, to be rearticulated on the national political stage through former students who went into prominent public positions or who set up or entered governing or opposition parties. As such, appreciating the ideas, behaviours and dreams that these people adopted during their university experiences can provide important insights into how they responded, as professionals and political leaders, to the challenges of economic crisis, structural adjustment and increasingly repressive authoritarian rule in the 1980s and 1990s.

From its inception as a form of subjectivity, African university studenthood gave its members a 'cosmopolitan mobility' over social and spatial orders that opened up a new sense of political possibility (Ivaska 2018). Aside from Fourah

\footnotetext{
Dan Hodgkinson is a departmental lecturer in African History and Politics at the University of Oxford. He has recently completed an oral history project on Rhodesian and Zimbabwean student activism from 1957 to the present. His research interests include histories of protest, oral history, African intellectual history and the politics of Southern Africa. Email: dan.hodgkinson@ qeh.ox.ac.uk

Luke Melchiorre is an assistant professor in the Department of Political Science at Universidad de los Andes in Bogotá, Colombia. He completed his $\mathrm{PhD}$ in political science at the University of Toronto in 2018. Email: jl.melchiorre@uniandes.edu.co
}

(C) International African Institute 2019 
Bay College in Sierra Leone, some universities in North Africa and a clutch of South African universities established by settlers, the idea of universities on the continent did not seriously 'enter the colonial imagination until quite late' (Cooper 2002: 111). ${ }^{1}$ As a result, educated Africans who became university students prior to World War Two were most often educated at institutions of higher learning in the metropole (Goebel 2015; Matera 2015). In London, for example, the Nigerian student Ladipo Solanke, with a small coterie of other West African students (most of whom were studying law), set up the West African Students' Union (WASU) in 1925, which became a fulcrum for elite African debate of anti-colonial ideas (Adi 1998). ${ }^{2}$ To these early students, their 'legal studies provided the basis for their criticism of British colonial rule', which was recognized by colonial authorities, as well as the belief that 'it was they, the intellectuals, who would become the leaders of the people' in independent Africa (Garigue 1953: 57). Many scholars have shown how WASU and other African university students during this period went on to play central roles leading anti-colonial nationalist movements (Anderson 2006; Ndlovu-Gatsheni 2009; Boehmer 2012; Livsey 2017). These metropolitan universities were troubling places of alienation and temptation within which many of the continent's foremost nationalist leaders, such Julius Nyerere, Amílcar Cabral and Eduardo Mondlane, faced European racism and developed their own anti-colonial politics. In this way, these formative experiences of higher education abroad served to inform these leaders' involvement in their respective colonies' fight for decolonization (Adi 1998; Schatman 2009; Blum et al. 2016; Molony 2014).

The elite status that underpinned anti-colonial student activism, as well as its subsequent manifestations covered in this special issue, was eroded in the late 1980s and 1990s. Over the last couple of decades, much of the academic work on student activism in Africa has focused on the impact of neoliberal restructuring of African higher education on trajectories of student activism on the continent. This body of scholarship has demonstrated the ways in which austerity reforms have contributed to the diminishing of students' once illustrious social status, facilitating their deeper collaboration in political activities with other urban constituencies, and directing the focus of their activism more to pressing 'bread and butter' issues relating to student welfare than overall concerns with national politics (Boyer 2000; Caffentzis 2000; Federici and Caffentzis 2000; Zeilig 2007; Zeilig and Dawson 2008; Nyamnjoh et al. 2012).

This special issue contends that to understand more recent forms of African student protest requires appreciating the legacies of student activism in the era of decolonization and particularly the closeness between university education and dominant ideas of state building. In response to widespread anti-colonial

\footnotetext{
${ }^{1}$ The creation of new colonial universities and a boom in international scholarships emerged after World War Two. The first universities founded in British Africa after the war were the University Colleges of Ibadan (1948), Makerere (1949) and Rhodesia and Nyasaland (1954). Similarly, Jesuits in the Belgian Congo founded the University of Lovanium (1954) in Leopoldville, French authorities established the University of Dakar (1957), and, in 1962, Portuguese authorities began centres of tertiary learning that became the Estudos Gerais Universitários de Angola (1968) and Estudos Gerais Universitários de Moçambique (1968).

${ }^{2}$ There has been particular scholarly interest in WASU, which includes 'The WASU Project'; see $<$ http://wasuproject.org.uk>.
} 
agitation in the 1950s, Frederick Cooper argues that colonial authorities 'came to envision a world that they no longer ruled but that they thought could function along principles they understood' (Cooper 2003: 36). In these imaginations of a decolonized world, state institutions and university-educated political elites played a reified role in the development of new nation states that were integrated into global markets and international organizations. As the international order began to be reshaped by Cold War dynamics, the modernizing belief that university students were critical to promoting 'socioeconomic and political models across the globe' was enhanced and new universities and scholarship schemes were set up in an attempt to shape the minds of these young students (Tournès and Scott-Smith 2018b: 15). The fact that Africa's era of decolonization 'coincided with the zenith of confidence in state-led development' (Young 2004: 2931) meant that lofty popular expectations about the potential fruits of independence were placed on the shoulders of African states' ascendant universityeducated nationalist leaders and on the universities that were expected to train them. As a result, throughout this era, even before students had set foot on campus, they were already codified according to their economic and political utility in the designs of powerful political and institutional authorities.

The articles in this special issue aim to chart this history and can be meaningfully grouped according to three central themes. The first theme explores the ways in which higher education acted as a significant vehicle of elite formation in postcolonial Africa, using, in many cases, oral histories to track how decolonization and its aftermath served to shape university students' aspirations in important ways and to inform their life and career trajectories, which often eventually led them to lead opposition political parties. The second theme considers the relations of ambivalence that developed between African states and university students in the era of decolonization, tracking the varied ways in which student activism and state power came to be mutually constitutive during this period. Finally, the third theme looks at the transnational dimensions of African university students' experience of higher education, charting the ways in which students' experiences of campuses on both sides of the Iron Curtain shaped their political ideas and expanded diaspora networks of solidarity.

In exploring these themes, these articles cover a diverse array of case studies from across African contexts. These include high-profile cases of student protest, for example in South Africa, which have received much scholarly attention, and cases such as Niger, which may not be as familiar to non-specialist readers. In exploring these cases, our authors rely on a wide range of source material, including oral histories, life histories and historical archives. As Tournès and Scott-Smith argue, in regard to international scholarship on this period, life histories are a particularly useful means of exploring how student experiences 'shaped career paths, disciplines, institutions and national cultures' (Tournès and ScottSmith 2018b: 4). In the case of the articles by Anne Heffernan, Dan Hodgkinson, Luke Melchiorre, Pedro Monaville and Marcia Schenck, extensive interviews with former student activists explore the politics of storytelling and memory and offer new empirical material that helps unearth previously understudied aspects of these histories, aspects that highlight the broader significance of the study of university students. Some of these articles, notably those by Rebecca Glade and Sara Pugach, also skilfully mine recently opened African and former communist state archives. Ultimately, while all of these contributions 
individually offer new insights on important histories, the gestalt of this special issue lies in appreciating the themes that tie them together.

\section{Aspirations, generation and oral history}

Since the 1970s, scholars of student activism have considered university education in late-colonial and newly independent African states as a mechanism in the formation of political and social elites (Barkan 1975; Burawoy 1976; Scudder and Colson 1980; Lentz 1994; West 2002; Fumanti 2016). During these years, the university was central to processes of social stratification, as students (and their families) saw education as a means of transforming themselves and their economic and social circumstances as well as a way of acquiring political and intellectual authority. Carola Lentz argued with regard to people in north-western Ghana that educational achievement caused both a material stratification, in terms of 'occupations, incomes, social networks, access to information, lifestyle', and a normative moral distinction between the uneducated and those university graduates (Lentz 1994: 154). The distinguishing effect of university education on students' expectations was also manifest in their political ambitions, in both late-colonial and postcolonial circumstances.

As recent scholarship has documented, the relationship of intense interdependence that was forged between African postcolonial states and their university students in the first decades after independence often came to be marked by deep ambivalence (Burgess and Burton 2010; Ivaska 2011). On the one hand, the universities were expected to provide these states with desperately needed high-level manpower, thus enabling the regimes to Africanize their expanding bureaucracies (Saul 1972; Mamdani 1994; Ivaska 2011). On the other hand, however, these statefunded universities could also serve unwittingly as 'incubator[s] of ... a political counter-elite' (Mamdani 2012: 86), providing university students with the space and time to foster solidarity and to develop and refine their political commitments and ideas. In an era when national leadership claims were often based on the assumption of superior scientific and technical knowledge (Ade Ajayi 1982), these university students' reified educational credentials afforded them the authority to exercise their voice and influence on the national political stage (Waller 2006: 80). As Michael Burawoy argues, the protests of postcolonial Zambian student activists against the government were based on the premise that the students 'regarded themselves as a deprived incipient elite' (Burawoy 1976: 94). Indeed, African student activists are often represented as 'temporary subversives, aspirant elites', in the words of Donal Cruise O'Brien (2003: 172), whose protests can be understood as 'mere attempts to appropriate a slice of the national cake [for themselves] and entry to the circle of the new elite' (Argenti 2002: 129). While reductive in scope, these instrumentalist studies rightly highlight the role of elite aspiration in motivating student protests of this period, as it was precisely when their aspirations were threatened or frustrated and their intellectual authority dismissed that demonstrations tended to occur (Ivaska 2011: 165).

All of the articles in this special issue build on and move beyond these insights to provide a more complex picture of the politics of students' elite aspirations. Several of the articles probe deeper into the specifics of how experiences of 
educational institutions - and their 'visible and invisible mobilities' - shaped African students' aspirations and the content of their politics (Summers 2002; Simpson 2003; Magaziner 2010; Nyamnjoh 2012; Ochiagha 2015). Summers and Heffernan examine the ways in which the processes of education were configured in colonial Uganda and apartheid South Africa and their implications for anti-colonial student activism and the Soweto Uprising in 1976. Using the life histories of four educationalists, Summers argues that, because 'the country's late colonial politics was a struggle over who was qualified to lead and govern', the type of student being produced in the colonial education system was a central concern. Summers shows how this imperative caused one educationalist to argue for strict regimes of corporal discipline - 'a system of flogging' - even at the most elite levels. Heffernan similarly looks at how black student activists who had become leaders of the Black Consciousness Movement subsequently became teachers and moved to Soweto, where they found jobs in schools and inspired their students with lessons of black empowerment.

Despite the continuity in the university's role as a mechanism of elite production between the late-colonial and independence eras, decolonization significantly changed the range of political aspirations open to student activists after independence. As Tom Burgess, Carola Lentz and Mattia Fumanti have shown, these generational differences were central to the type of politics that student activists developed (Lentz 1994; Burgess 1999; Fumanti 2016). In postcolonial political terrains, student activists sought particular forms of political inspiration in which to anchor their politics. As Pedro Monaville shows, for several generations of Congolese students following the death of Patrice Lumumba in 1961, the former prime minister became a powerful symbol who both inspired and was shaped and reshaped by students' political opposition to the Mobutu regime. Because of their elite status, as Monaville, Hodgkinson and Melchiorre show, the specificity of these student political deliberations often subsequently shaped national politics as these activists attempted to realize their own political aspirations.

The progression of the generation of independence-era student activists into national political careers provides fertile terrain for oral history. Monaville, Hodgkinson, Melchiorre, Glade, Schenck and Heffernan all use oral history methods to show how experiences of student activism shaped the trajectories of people's political careers and lives, particularly in the era of structural adjustment and multi-party democratization. Through the life history of an Angolan woman, Maria, who was educated in the German Democratic Republic (GDR), Schenck shows how these experiences were narrated nostalgically, in part because of the importance that Maria's German education played in ensuring her a prominent position in the MPLA. While Schenck addresses the stories of independence-era student political aspirations that were fulfilled, many were also frustrated. This was the case with the three Zimbabwean former ZANU(PF) leaders discussed in Hodgkinson's article. As students, these men all protested against the white Rhodesian state and then left the country, where they joined the party's external structures and furthered their political aspirations. After high-profile careers in independent Zimbabwe, all of these men either left the party or were pushed out. Hodgkinson shows how, rather than affirming a 'patriotic' nationalist narrative of their student activist pasts, these men used their stories to narrate alternative versions of the transformative politics that they claimed to have protested for 
as students. These nostalgic and frustrated narrations all illustrate the extent to which this generation of students used stories of their past activism to justify or critique their present-day circumstances.

\section{Trajectories of student activism and state power}

The relationship between African postcolonial states and their national universities has been a central preoccupation of Africanist scholars of student activism on the continent for decades (Ajayi et al. 1996; Balsvik 1998; Barkan 1975; Burawoy 1976; Hanna 1975; Ivaska 2011; Mamdani 1994; Young 1981). As already noted, following the decolonization of African states, newly created national universities did not simply represent 'visible national monuments to independence' (Mwira 1996 quoted in Klopp and Orina 2002: 47); they were also expected to play a practical role in state-led projects of nation building and development, helping 'to secure the precarious national unity and identity' (Young 1981: 147) of these new states, while also educating a new cadre of trained experts who would lead state-led development efforts. The supposed centrality of universities to African postcolonial states often meant that national politics came to loom large in the life of the African university. Indeed, as Melchiorre's article demonstrates in the case of Kenya, in many African countries this was most clearly represented in the common practice of appointing the President of the Republic as chancellor of the national university. Such appointments had the effect of bringing 'national politics to ... campus with much increased immediacy, and endowed university domestic issues with an uncomfortable measure of national significance' (Ajayi et al. 1996: 117).

During the initial post-independence decades, student protests on campuses across the continent came to represent some of the most public challenges levied against postcolonial regimes by any social group (Zeilig 2009). In Sudan, for example, in October 1964, student protests at Khartoum University were 'instrumental in ... the uprising that brought down the military government of General Ibrahim Abboud' (Argenti 2002: 129). In Senegal, in the spring of 1968 , demonstrations organized by students, in collaboration with trade unionists, forced the country's President Léopold Senghor to flee the capital and almost brought down his government in the process (Cruise O'Brien 2003: 169; Zeilig 2009; Bianchini 2016; Gueye 2017; Nugent 2012: 200-1). Perhaps most notably, African students' protracted struggles against repressive state apparatuses in Ethiopia and South Africa during the 1970s and 1980s played a crucial role in the toppling of these regimes (Bundy 1987; Zewde 2014). These protests in the first decade of the independence era precipitated a shift in postcolonial states to more effectively discipline and manage their student populations. Initial state responses often attempted to more extensively 'incorporate the university under the surveillance of dominant political organs' (Burawoy 1976: 94), be it through the establishment of campus party youth wings, as in Siaka Stevens' Sierra Leone (Abdullah 1998), or through the appointment of high-ranking party officials to positions of power within the university administration, as in Nyerere's Tanzania (Melchiorre 2018). 
Over time, the nature of African states' relationships with their national universities changed. As Mamdani (1994: 3) has argued, with the onset of financial crisis in African countries beginning in the late 1970s, African states' rhetoric about their national universities shifted from an emphasis on 'development' to a growing preoccupation with 'law and order', which increasingly eschewed state strategies of co-optation for more repressive responses to dissident student activists. Complicating Mamdani's argument, however, the articles in this special issue provide a more nuanced account of the varied ways in which these historical trajectories unfolded in practice. In so doing, the combined findings of the articles here offer an implicit critique of a tendency in contemporary Africanist political scholarship towards overgeneralizing postcolonial state trajectories. This inclination has served to 'flatten the African [political] landscape' (Nugent 2010: 35), obscuring the significant variations that marked the institutional choices made by Africa's first generation of state builders (Boone 2004: 321; Cheeseman 2018: 20-1; Melchiorre 2018; Nugent 2010: 35-8). While the articles in this special issue identify important commonalities in the relationships that developed between African postcolonial states and their national universities, they also use these relationships as a lens through which to better appreciate the diverse and dynamic ways in which state power in postcolonial Africa was exercised during this period. In so doing, they illuminate the various guises that this power assumed on university campuses both across and within specific contexts.

Melchiorre's article, for example, documents the case of Kenya, one of the continent's most historically fraught relationships between state and university students. Here, more than a decade of increasingly repressive tactics used by the Kenyan state against university students eventually led the government of the country's second president, Daniel arap Moi, to introduce a specially designed National Youth Service pre-university training programme (NYSPUT). NYSPUT attempted to instil discipline and inculcate loyalty into prospective Kenyan university students through a compulsory programme of paramilitary training prior to their arrival on campus. In examining this project, Melchiorre explores its unintended consequences, demonstrating how experiences of the camp frustrated and militarized student critics of the regime, who, when they later arrived at university, presented the Moi government with some of its most public, defiant challenges of the period. In contrast, Smirnova's article describes a very different kind of state-student relationship during these same crucial decades. While the Nigerien state, like its Kenyan counterpart, ultimately resorted to the deployment of state violence against dissident student activists in the 1980s, this occurred only following a decade within which the regimes of Diori Hamani and Seyni Kountché sought to pursue a strategy, not of repression, but of cooptation. In 1970s Niger, the government permitted student activists a fairly open political space within which to organize, at least by Kenyan standards, in the hope that such a strategy would help them co-opt these students into the state's overarching hegemonic order. As Smirnova notes, such attempts culminated with Kountché government ministers holding five days of formal negotiations with student leaders in May 1982 prior to the visit of the French president, François Mitterrand.

While attempting to eschew any homogeneous characterizations of the African postcolonial state, the articles in this special issue also avoid the schizophrenic 
tendency to portray university students in Africa as either co-opted elites-in-themaking collaborating with authoritarian regimes or as heroic protestors fighting for more democratic dispensations. Such binary depictions are challenged by articles such as Glade's, which reveals how student supporters of two marginal national political parties engaged in fervent debates about the desired characteristics of the country's emergent nation. These debates came to dominate student political life on the campus of the University of Khartoum in the late 1960s. While the articles in this special issue are careful not to present student activists as monolithic entities, they do demonstrate how, at institutions of higher learning both on the continent and beyond, African students were able to use the space of the university and their reified intellectual status, at certain moments, to construct counter-hegemonic and, at times, radical political projects that confounded both African states' top-down initiatives and the authority that underpinned them.

\section{Student activism's transnational and spatial dimensions}

This special issue also builds on recent African histories of the Cold War and the 1960s that have considered the complex ways in which local events of this period can meaningfully be considered part of a 'global' phenomenon (Gueye 2017; Hodgkinson 2018; Ivaska 2018; Monaville 2018; Rillon 2018). This new turn in historical scholarship has sought to expand and complicate national histories by exploring the exact processes that emerged in the second half of the twentieth century and through which transnational dimensions shaped local political, intellectual and social change (Roberts 2016; Alexander and McGregor 2017; Pearce 2017). The expansion of university systems and scholarship schemes in the era of decolonization across Africa, the communist East and the capitalist West makes African university students an obvious subject in this new historiography (Tournès and Scott-Smith 2018a). In African states such as Nigeria, Senegal, Sierra Leone, Ghana, Tanzania, Uganda and Zambia, nationalist leaders who were inspired by Pan-Africanist notions of solidarity and development established scholarship schemes for African students, in particular for black students in the white-settler regimes of Southern Africa (Grilli 2015).

In considering the political importance of these 'dense networks of knowledge and cultural transfer' (Tournès and Scott-Smith 2018b: 4), this special issue builds on the work of Victoria Langland, who calls for an approach that distinguishes between the 'literal' connections - 'the routes taken by actual people, specific ideas, sources of funds, and so forth' - and the more nebulous 'aspirational' connections, which relate to the 'collectively held belief that unknown others in the world share a similar set of ideas and goals' (Langland 2018: 31). The literal connections that African students opened up with other areas of the world presented opportunities for broader African political movements, in particular those from Southern Africa that were fighting against white-settler rule (Hessler 2006; Matusevich 2009; Katsakioris 2014; Pugach 2015; Slobodian 2015). International student networks provided footholds for liberation movements to create new solidarities and social movements in foreign countries, which were important in pressuring foreign governments and in fundraising (Ndlovu 2016; Mazarire 2017). 
These literal connections also exposed students to new social circumstances and fostered the development of their political ideas, which could later be used to challenge nationalist leaders. Sara Pugach, for example, shows in her examination of African students in the GDR how Guinean students' leftist commitment to solidarity with Guinean striking teachers in 1961 caused acute embarrassment to Ahmed Sékou Touré's government. The difficulties that independent African governments, such as Touré's, had in disciplining or controlling postcolonial student politics practised beyond the borders of the postcolonial state often meant that radical forms of politics emerged in international student enclaves.

The radical politics of such enclaves could also have significant effects on the politics of the host countries. As Ishmail Rashid argues, many of the Sierra Leonean student leaders of the late 1970s who went on to form the Revolutionary United Front (RUF) were initially inspired to demonstrate by Zimbabwean students in 1977 at Fourah Bay 'in support of their country's struggle' (Rashid 1997). The influence of student movements on one another did not depend on literal connections alone. Aspirational transnational connections and shared ideas of PanAfrican solidarity were also important in shaping student activism within Africa and beyond. Events such as Patrice Lumumba's assassination in 1961, the Rhodesian Front's Unilateral Declaration of Independence in 1965 and the Soweto Uprising in 1976 became symbols of a form of global imperialism against which student movements from across the world mobilized. Focusing on the death of Lumumba, Pedro Monaville reveals the ways in which his assassination was commemorated and remade by Congolese students at universities across the world to create a powerful form of oppositional politics to that of Mobutu.

While these novel transnational approaches to the study of student activism have highlighted the importance of spatial mobility, new approaches should not ignore the role that internal migrations can play in deepening the political influence of student politics within countries. Anne Heffernan makes this point in the context of South Africa through the lives of three Black Consciousness Movement student activists. These men went from being student leaders in the early 1970s to becoming teachers in South Africa's townships, where they were critical in inspiring the generation of schoolchildren who led the Soweto Uprising in 1976.

$* * *$

The origins of this special issue were inspired in part by African university students' recent efforts to decolonize academic knowledge production. In African studies today, a crucial aspect of this agenda is to significantly expand the role played by African scholars in shaping knowledge production about the continent at institutions in the global North, whether it be through staffing hires, academic journals, or attendances on conference panels or at workshops. The fact that no African authors' contributions have been published in this special issue represents, in spite of our efforts, a failure to meaningfully advance this aspect of the decolonizing agenda. This failure has challenged us to think through how, as junior white scholars, we engage in collaborative academic projects. First, what barriers exist for initiating collaborative historical or social science research projects between African and non-African doctoral students and junior scholars, and how can these be overcome? Second, how, in circumstances with little access to finance, can junior scholars maintain academic collaborations between (and 
within) Northern and non-Northern universities? For example, in organizing a workshop like ours, how best can we practically support scholars based on the continent who have significantly more constrained access to research support and travel funding? Lastly, what responsibilities do senior academics, academic journals and university departments have in creating or encouraging these collaborations? Should doctoral programmes make such collaborations a requirement? Should academic journals not publish a special issue such as ours, where the work of African scholars has not been included?

\section{References}

Abdullah, I. (1998) 'Bush path to destruction: the origin and character of the Revolutionary United Front/Sierra Leone', Journal of Modern African Studies 36 (2): 203-35.

Ade Ajayi, J. F. (1982) 'Expectations of independence', Daedalus 111 (2): 1-9.

Adi, H. (1998) West Africans in Britain 1900-1960: nationalism, Pan-Africanism and communism. London: Lawrence and Wishart.

Ajayi, J. F., L. K. H. Goma and A. G. Johnson (1996) The African Experience with Higher Education. Athens OH: Ohio University Press.

Alexander, J. and J. McGregor (2017) 'African soldiers in the USSR: oral histories of ZAPU intelligence cadres' Soviet training, 1964-1979', Journal of Southern African Studies 43 (1): 49-66.

Anderson, B. (2006) Imagined Communities: reflections on the origin and spread of nationalism. London and New York NY: Verso.

Argenti, N. (2002) 'Youth in Africa: a major resource for change' in A. de Waal and N. Argenti (eds), Young Africa: realising the rights of children and youth. Trenton NJ: Africa World Press.

Balsvik, R. R. (1998) 'Student protest: university and state in Africa 1960-1995', Forum for Development Studies 2: 301-25.

Barkan, J. D. (1975) An African Dilemma: university students, development and politics in Ghana, Tanzania and Uganda. Oxford: Oxford University Press.

Bianchini, P. (2016) 'The three ages in student politics in Africa: learning from the cases of Senegal and Burkina Faso' in T. Luescher-Mamashela, M. Klemencic and J. Jowi (eds), Student Politics in Africa: representation and activism. Cape Town: African Minds.

Blum, F. et al. (2016) Étudiants africains en mouvements: contribution à une histoire des années 1968. Paris: Publications de la Sorbonne.

Boehmer, E. (2012) Stories of Women: gender and narrative in the postcolonial nation. Manchester: Manchester University Press.

Boone, C. (2004) Political Topographies of the African State. Cambridge: Cambridge University Press.

Booysen, S. (ed.) (2016) Fees Must Fall: student revolt, decolonization and governance in South Africa. Johannesburg: Wits University Press.

Boyer, D. (2000) 'The African crisis in context: comparative encounters with educational rationalization', African Studies Review 45 (2): 205-18.

Bundy, C. (1987) 'Street sociology and pavement politics: aspects of youth and student resistance in Cape Town, 1985', Journal of Southern African Studies 13 (3): 303-30. 
Burawoy, M. (1976) 'Consciousness and contradiction: a study of student protest in Zambia', British Journal of Sociology 27 (1): 78-98.

Burgess, G. T. (1999) 'Remembering youth: generation in revolutionary Zanzibar', Africa Today 46 (2): 28-50.

Burgess, G. T. and A. Burton (2010) 'Introduction' in A. Burton and H. ChartonBigot (eds), Generations Past: youth in East African history. Athens OH: Ohio University Press.

Caffentzis, G. (2000) 'The World Bank and education in Africa' in S. Federici, G. Caffentzis and O. Alidou (eds), A Thousand Flowers: social struggles against structural adjustment in African universities. Trenton NJ and Asmara: Africa World Press.

Cheeseman, N. (2018) 'Understanding African politics: bringing the state back in' in N. Cheeseman (ed.), Institutions and Democracy in Africa. Cambridge: Cambridge University Press.

Cooper, F. (2002) Africa Since 1940: the past of the present. Cambridge: Cambridge University Press.

Cooper, F. (2003) 'Conflict and connection: rethinking colonial African history' in J. D. Le Sueur (ed.), The Decolonization Reader. New York NY and London: Routledge.

Cruise O'Brien, D. (2003) Symbolic Confrontations: Muslims imagining the state in Africa. London: Hurst.

Federici, S. and G. Caffentzis (2000) 'Chronology of African university students' struggles: 1985-1998' in S. Federici, G. Caffentzis and O. Alidou (eds), A Thousand Flowers: social struggles against structural adjustment in African universities. Trenton NJ and Asmara: Africa World Press.

Fumanti, M. (2016) The Politics of Distinction: African elites from colonialism to liberation in a Namibian frontier town. Canon Pyon: Sean Kingston Publishing.

Garigue, P. (1953) 'The West African Students' Union: a study in culture contact', Africa 23 (1): 55-69.

Goebel, M. (2015) Anti-imperial Metropolis: interwar Paris and the seeds of Third World nationalism. Cambridge: Cambridge University Press.

Grilli, M. (2015) 'African liberation and unity in Nkrumah's Ghana (1957-1966)'. $\mathrm{PhD}$ thesis, University of Pavia.

Gueye, O. (2017) Mai 1968 au Sénégal: Senghor face aux étudiants et au mouvement syndical. Paris: Karthala.

Hanna, W. J. (1975) University Students and African Politics. New York NY: Africana.

Heffernan, A., N. Nieftagadien, S. M. Ndlovu and B. Peterson (eds) (2016) Students Must Rise: youth struggle in South Africa before and beyond Soweto. Johannesburg: Wits University Press.

Hessler, J. (2006) 'Death of an African student in Moscow', Cahiers du Monde Russe 47 (1): 33-63.

Hodgkinson, D. (2018) 'Subversive communities and the "Rhodesian sixties": an exploration of transnational protests, 1965-1973' in C. Jian, M. Klimke, M. Kirasirova et al. (eds), The Routledge Handbook of the Global Sixties. Abingdon: Routledge.

Ivaska, A. (2011) Cultured States: youth, gender, and modern style in 1960s Dar es Salaam. Durham NC: Duke University Press. 
Ivaska, A. (2018) 'Liberation in transit: Eduardo Mondlane and Che Guevara in Dar es Salaam' in C. Jian, M. Klimke, M. Kirasirova et al. (eds), The Routledge Handbook of the Global Sixties. Abingdon: Routledge.

Katsakioris, C. (2014) 'The Soviet-South encounter: tensions in the friendship with Afro-Asian partners, 1945-1965' in P. Barbiracki and K. Zimmer (eds), Cold War Crossings: international travel and exchange across the Soviet bloc, 1940s-1960s. Arlington TX: University of Texas Press.

Klopp, J. M. and J. R. Orina (2002) 'University crisis, student activism, and the contemporary struggle for democracy in Kenya', African Studies Review 45 (1): 43-76.

Langland, V. (2018) 'Transnational connections of the global sixties as seen by a historian of Brazil' in C. Jian, M. Klimke, M. Kirasirova et al. (eds), The Routledge Handbook of the Global Sixties. Abingdon: Routledge.

Lentz, C. (1994) 'Home, death and leadership: discourses of an educated elite from north-western Ghana', Social Anthropology 2 (2): 149-69.

Livsey, T. (2017) Nigeria's University Age: reframing decolonisation and development. London: Palgrave Macmillan.

Magaziner, D. R. (2010) The Law and the Prophets: black consciousness in South Africa, 1968-1977. Athens OH: Ohio University Press.

Mamdani, M. (1994) 'Intelligentsia, the state, and social movements in Africa' in M. Diouf and M. Mamdani (eds), Academic Freedom in Africa. Cape Town: CODESRIA.

Mamdani, M. (2012) Define and Rule: native as political identity. Cambridge MA: Harvard University Press.

Matera, M. (2015) Black London: the imperial metropolis and decolonization in the twentieth century. Oakland CA: University of California Press.

Matusevich, M. (2009) 'Black in the USSR: African, African Americans, and the Soviet society', Transition 100: 56-75.

Mazarire, G. C. (2017) 'ZANU's external networks 1963-1979: an appraisal', Journal of Southern African Studies 43 (1): 83-106.

Melchiorre, L. (2018) 'Building nations, making youth: institutional choice, nation-state building and the politics of youth activism in postcolonial Kenya and Tanzania'. PhD thesis, University of Toronto.

Molony, D. (2014) Nyerere: the early years. London: James Currey.

Monaville, P. (2018) 'Making a "second Vietnam": the Congolese revolution and its global connections in the 1960s' in C. Jian, M. Klimke, M. Kirasirova et al. (eds), The Routledge Handbook of the Global Sixties. Abingdon: Routledge.

Mwira, K. (1996) 'Democratizing Kenya's university education sector' in Sectoral Studies: Focussing on Kenya's Future Policy Reforms. Vol. 1. Nairobi: International Commission of Jurists.

Ndlovu, S. (2016) 'South African youth and students in exile: the politics of solidarity and popular mobilisation'. Paper presented at the conference 'Global history of the anti-apartheid movement', University of Oxford, 11-12 March.

Ndlovu-Gatsheni, S. J. (2009) Do 'Zimbabweans' Exist? Trajectories of nationalism, national identity formation and crisis in a postcolonial state. Bern: Peter Lang.

Nugent, P. (2010) 'States and social contracts in Africa', New Left Review 63: 35-68.

Nugent, P. (2012) Africa Since Independence. London: Palgrave Macmillan. 
Nyamnjoh, F. B. (2012) “"Potted plants in greenhouses": a critical reflection on the resilience of colonial education in Africa', Journal of Asian and African Studies 47 (2): 129-54.

Nyamnjoh, F. B. et al. (2012) University Crisis and Student Protest in Africa: the 2005-6 university students strike in Cameroon. Bamenda: Langaa.

Nyamnjoh, F. B. (2016) Rhodes Must Fall: nibbling at resilient colonialism in South Africa. Bamenda: Langaa Research and Publishing Common Initiative Group. Ochiagha, T. (2015) Achebe and Friends at Umuahia: the making of a literary elite. Woodbridge: James Currey.

Pearce, J. (2017) 'Global ideologies, local politics: the Cold War as seen from central Angola', Journal of Southern African Studies 43 (1): 13-27.

Pugach, S. (2015) 'African students and the politics of race and gender in the German Democratic Republic, 1957-1990' in Q. Slobodian (ed.), Comrades of Color: East Germany in the Cold War world. New York NY: Berghahn Books.

Rashid, I. (1997) 'Subaltern reactions: students, lumpens, and the left', African Development 22 (3-4): 19-44.

Rillon, O. (2018) 'Rebellious bodies: urban youth fashion in the sixties and seventies in Mali' in C. Jian, M. Klimke, M. Kirasirova et al. (eds), The Routledge Handbook of the Global Sixties. Abingdon: Routledge.

Roberts, G. (2016) 'Politics, decolonisation, and the Cold War in Dar es Salaam c.1965-72'. PhD thesis, University of Warwick.

Saul, J. S. (1972) 'Planning for socialism in Tanzania: the socio-economic context', Development and Change 3 (3): 3-25.

Schatman, T. (2009) Airlift to America: how Barack Obama Sr., John F. Kennedy, Tom Mboya, and 800 East African students changed their world and ours. New York NY: St Martin's Press.

Scudder, T. and E. Colson (1980) Secondary Education and the Formation of an Elite: the impact of education on Gwembe District, Zambia. New York NY: Academic Press.

Simpson, A. (2003) 'Half London' in Zambia: contested identities in a Catholic mission school. Edinburgh: Edinburgh University Press.

Slobodian, Q. (ed.) (2015) Comrades of Color: East Germany in the Cold War world. New York NY: Berghahn Books.

Summers, C. (2002) Colonial Lessons: Africans' education in Southern Rhodesia, 1918-1940. Oxford: James Currey.

Tournès, L. and G. Scott-Smith (eds) (2018a) Global Exchanges: scholarships and transnational circulations in the modern world. Oxford: Berghahn Books.

Tournès, L. and G. Scott-Smith (2018b) 'A world of exchanges: conceptualizing the history of international scholarship programmes (19th to 21st century)' in L. Tournès and G. Scott-Smith (eds), Global Exchanges: scholarships and transnational circulations in the modern world. Oxford: Berghahn Books.

Waller, R. (2006) 'Rebellious youth in colonial Africa', Journal of African History 47 (1): 77-92.

West, M. O. (2002) The Rise of an African Middle Class: colonial Zimbabwe, 1898-1965. Bloomington and Indianapolis IN: Indiana University Press.

Young, C. (2004) 'The end of the post-colonial state in Africa? Reflections on changing African political dynamics', African Affairs 103 (410): 23-49.

Young, M. C. (1981) 'The African university: universalism, development and ethnicity', Comparative Education Review 25 (2): 145-63. 
Zeilig, L. (2007) Revolt and Protest: student politics and activism in sub-Saharan Africa. London: I. B. Tauris.

Zeilig, L. (2009) 'Student resistance and the democratic transition: student politics in Senegal 1999-2005', Social Dynamics 35 (1): 68-93.

Zeilig, L. and M. Dawson (2008) 'Introduction: student activism, structural adjustment and the democratic transition in Africa', Journal of Higher Education in Africa 6 (2-3): 1-31.

Zewde, B. (2014) The Quest for Socialist Utopia: the Ethiopian student movement, c. 1969-1974. Woodbridge: James Currey. 